\title{
Origin and dispersal routes of foreign green and Kemp's ridley turtles in Spanish Atlantic and Mediterranean waters
}

\author{
Carlos Carreras ${ }^{1,2,3, *}$, Catalina Monzón-Argüello ${ }^{3,4}$, Luis Felipe López-Jurado ${ }^{5}$, Pascual Calabuig ${ }^{6}$, \\ Juan Jesús Bellido ${ }^{7}$, Juan José Castillo ${ }^{7}$, Pablo Sánchez ${ }^{8,9}$, Pas Medina ${ }^{8}$, Jesús Tomás ${ }^{10}$, \\ Patricia Gozalbes ${ }^{10}$, Gloria Fernández ${ }^{11}$, Adolfo Marco $^{3}$, Luis Cardona ${ }^{1}$
}

\begin{abstract}
The presence of the green and Kemp's ridley turtles is rare at Atlantic and Mediterranean Spanish waters, but the records have increased during the last decades. We reported a new set of records and reviewed all the historical observations of these species. The analysis of a mitochondrial DNA fragment of the newest records provided insights about the origin of the individuals. The Kemp's ridley turtles arrived from the western Atlantic nesting beaches, although the discovering of a new haplotype suggested the existence of an unknown or low sampled nesting area of origin. Furthermore, the genetic analysis was crucial for the species identification in one specimen, hence recommending the use of genetic markers to confirm the presence of a rare species. All green turtles presented haplotypes exclusive from Atlantic nesting beaches and concentrated in the African populations. Thus, the closest eastern Mediterranean nesting areas were discarded as source populations and a new migration route for this species was described.
\end{abstract}

Keywords: Chelonia mydas, dispersal, Lepidochelys kempii, migration, mtDNA, rare species, Spanish marine waters.

\section{Introduction}

1 - Department of Animal Biology, Faculty of Biology, University of Barcelona, Avda. Diagonal 643, 08028 Barcelona, Spain

2 - Centre for Ecology and Conservation, University of Exeter, Cornwall Campus, Penryn, TR10 9EZ, UK

3 - Estación Biológica de Doñana, CSIC, c/Américo Vespucio s/n, 41092 Sevilla, Spain

4 - Asociación para el Desarrollo Sostenible y Conservación de la Biodiversidad, c/Blas de Lezo $55,1^{\circ} \mathrm{G}$, 35118 Las Palmas de Gran Canaria, Spain

5 - Departamento de Biología, Universidad de Las Palmas de Gran Canaria, Campus de Tafira, 35017 Las Palmas de Gran Canaria, Spain

6 - Centro de Recuperación de Fauna Silvestre de Tafira, Crta. del Centro km 7, 35017 Las Palmas de Gran Canaria, Spain

7 - CREMA (Centro de Recuperación de Especies Marinas Amenazadas), Aula del Mar de Málaga - Consejería de Medio Ambiente de la Junta de Andalucía, Avda. Manuel Agustín Heredia 35, 29001 Málaga, Spain

8 - Marine Animal Rescue Center (CRAM), Passeig de la Platja 28-30, 08820 El Prat de Llobregat, Spain

9 - Laboratori d'Ictiologia Genètica, Departament de Biologia, Universitat de Girona, Campus Montilivi, 17071 Girona, Spain

10 - Cavanilles Institute of Biodiversity and Evolutionary Biology, University of Valencia, P.O. Box 22085, 46071 Valencia, Spain

11 - Fundación Aspro Natura, c/Garcilaso de la Vega 9, 07181 Costa d'en Blanes, Calvià, Spain

*Corresponding author;

e-mail: c.carreras-huergo@exeter.ac.uk
The study and conservation of marine turtles is often challenging due to their complex life cycles that extend across vast spatial and temporal scales (Miller, 1997; Musick and Limpus, 1997). In contrast to this mobility, the high degree of philopatry showed by almost all species (Miller, 1997), might cause the isolation of some populations, and lead to severe conservation problems if they decrease without the incoming of, at least, few migrants from other populations (Bowen and Karl, 1997). Furthermore the existence of distant shared feeding areas used by different populations makes difficult to attribute the impact of any spatially defined threats to the populations of origin (Bowen and Karl, 2007). Finally, the migratory behaviour of marine turtles and the inherent difficulties of the research at sea complicate the assessment of the migratory routes and the real range of distribution of the populations. For all these reasons, the identification of migratory routes, putative shared feeding grounds and the range of distribution are basic elements to assess isolation of the most threatened populations and to 
define the Management Units (MUs; Moritz, 1994) and Regional Management Units of the species (RMUs; Wallace et al., 2010). Even if only a few individuals are detected, their records are relevant, as they represent only a small fraction of the animals inhabiting the area. Thus, the determination of the origin and migratory routes of the scarce individuals found in areas far from their known range of distribution can raise interesting questions, especially on endangered species (e.g. Sheinin et al., 2011).

Marine turtles occur both along the Mediterranean and Atlantic coasts of Spain (Camiñas, 2002; Carreras and Tomás, 2010) but natural nesting activity is almost absent (Tomás et al., 2008). The loggerhead turtle (Caretta caretta) is the most common species, with most of the sightings and strandings corresponding to juveniles or early adults that migrate both from Atlantic and eastern Mediterranean nesting areas (Laurent et al., 1993; Laurent et al., 1998; Carreras et al., 2006; Monzon-Arguello et al., 2009; Carreras et al., 2011). Other marine turtle species occur in the area in much lower numbers (López-Jurado and Liria, 2007; Carreras and Tomás, 2010), including a few records of green turtles (Chelonia mydas) and Kemp's Ridley turtles (Lepidochelys kempii) over the past 150 years (table 1). The presence of these last two species in Spanish waters have been considered traditionally as anecdotal (Camiñas, 2002), but such reports raise questions not only about the origin of the individuals but also on its true species. While green turtles are easily diagnosed by long frontal scales and four coastal carapace scutes (Pritchard and Mortimer, 1999), the two turtles of the genus Lepidochelys ( $L$. kempii and L. olivacea) can be easily confused by inexpert observers, or even confused with loggerhead juveniles that present a similar scute pattern. The nesting grounds of olive ridley ( $L$. olivacea) in Africa are at similar distances to Spain as the nesting grounds of Kemp's ridley (L. kempii) in the northwestern Atlantic, thus suggesting that the former species may also reach Spain.
The green turtle is the second most abundant nesting marine turtle species in the Mediterranean but its presence as a nester is limited to the eastern basin (Casale and Margaritoulis, 2010). This species has been considered only an occasional visitor to Spanish waters despite continuous reports since the second half of the $19^{\text {th }}$ century (Machado, 1859; Barcelo, 1876; Boscá, 1877), as records were very dispersed in time and space. Most of these records did not include the size of the animals but the few data available suggest that almost all individuals would be juveniles, although some adult animals could also be present. As this species nests within the Mediterranean, the RMU comprising the eastern nesting areas have traditionally been suggested as the most likely origin for the green turtles found in Spanish waters (Pascual, 1985; Camiñas, 2002), but further research with this species has demonstrated a high dispersal capacity during the juvenile, pelagic stage (Monzon-Arguello et al., 2010) and thus the Atlantic RMUs (Wallace et al., 2010) cannot be discarded as putative origin for these records. In contrast, the presence of the Kemp's ridley turtle in Spanish waters has not been detected until recently, with a few records of juveniles (Fernández de la Cigoña, 1994; Pérea et al., 2001; Camiñas, 2002; Tomás et al., 2003; Tomás and Raga, 2008).

Marine turtles are known to undertake some of the longest known migration routes of living animals (Lohmann et al., 1997) and hence the putative population where they come from could be at thousands of kilometres distant from the location they are found. Furthermore, Spanish waters are known feeding grounds for very distant populations of the common loggerhead turtle (Laurent et al., 1993; Laurent et al., 1998; Carreras et al., 2006; Monzon-Arguello et al., 2009; Carreras et al., 2011) and if these species with scarce reports follow the same routes than the loggerheads, the origin of those animals could be also very variable, and include both sides of the Atlantic or the Mediterranean depending on the species. Despite its threat- 
Table 1. Historical records of green and Kemp's ridley turtles in Spanish waters without genetic data.

\begin{tabular}{|c|c|c|c|}
\hline Species & Location & Date & Reference \\
\hline $\begin{array}{l}\text { C. mydas } \\
\quad(n=26)\end{array}$ & $\begin{array}{l}\text { Cabrera Island (M) } \\
\text { Mallorca Island (M) } \\
\text { Mallorca Island (M) } \\
\text { Ría de Vigo (A) } \\
\text { Ría de Arosa (A) } \\
\text { Ría de Pontevedra (A) } \\
\text { Mediterranean (ns) (M) } \\
\text { Cadiz (A) } \\
\text { Columbretes Islands (M) } \\
\text { Ría de Arosa (A) } \\
\text { Tenerife Island (A) } \\
\text { Canary Islands (ns) (A) } \\
\text { Tenerife Island (A) } \\
\text { Gran Canaria Island (A) } \\
\text { Lanzarote Island (A) } \\
\text { Ebro Delta (M) } \\
\text { Ebro Delta (M) } \\
\text { Ebro Delta (M) } \\
\text { Ebro Delta (M) } \\
\text { Chafarinas Islands (M) } \\
\text { Huelva (A) } \\
\text { Sanlúcar de Barrameda (A) } \\
\text { Doñana National Park (A) } \\
\text { Cadiz (A) } \\
\text { Ebro Delta (M) } \\
\text { Huelva (A) }\end{array}$ & $\begin{array}{c}06 / 1850 \\
1865 \\
1865 \\
* \\
* \\
* \\
<1985 \\
<1859 \\
07 / 1859 * \\
07-08 / 1959 \\
* \\
<1960 \\
<2002 \\
<2002 \\
<2002 \\
29 / 12 / 98 \\
20 / 03 / 99 \\
28 / 07 / 00 \\
18 / 6 / 93 \\
<2002 \\
09 / 1995 \\
02 / 2002 \\
07 / 2003 \\
09 / 2005 \\
12 / 2007 \\
08 / 2009\end{array}$ & $\begin{array}{l}\text { Barcelo, 1876; Pascual, } 1985 \\
\text { Barcelo, 1876 } \\
\text { Barcelo, 1876 } \\
\text { Boscá, 1877; López Seoane, 1877; Pascual, } 1985 \\
\text { Boscá, 1877; López Seoane, 1877; Pascual, } 1985 \\
\text { Boscá, 1877; López Seoane, 1877; Pascual, } 1985 \\
\text { Pascual, 1985 } \\
\text { Machado, 1859; Boscá, 1877; Pascual, } 1985 \\
\text { Boscá, 1916; Pascual, 1985 } \\
\text { Brongersma, 1967; Brongersma, 1972; Pascual, } 1985 \\
\text { Loveridge and Williams, 1957; Pascual, } 1985 \\
\text { Pasteur and Bons, 1960; Pascual, 1985 } \\
\text { Camiñas, 2002 } \\
\text { Camiñas, 2002 } \\
\text { Camiñas, 2002 } \\
\text { Bertolero, 2003 } \\
\text { Bertolero, } 2003 \\
\text { Bertolero, } 2003 \\
\text { Bertolero, 2003 } \\
\text { Camiñas, 2002 } \\
\text { present study } \\
\text { present study } \\
\text { present study } \\
\text { present study } \\
\text { present study } \\
\text { present study }\end{array}$ \\
\hline $\begin{array}{l}\text { L. kempii } \\
\qquad(n=10)\end{array}$ & $\begin{array}{l}\text { Galicia (A) } \\
\text { Galicia (A) } \\
\text { Asturias (A) } \\
\text { Vizcaya Gulf (A) } \\
\text { Andalusia (ns) (M, A) } \\
\text { Andalusia (ns) (M, A) } \\
\text { Ceuta (M) } \\
\text { Valencia (M) } \\
\text { Huelva (A) } \\
\text { Rota (A) }\end{array}$ & $\begin{array}{l}<1994 \\
<1994 \\
<2001 \\
<2002 \\
<2002 \\
<2002 \\
<2002 \\
07 / 2006 \\
10 / 2005 \\
08 / 2008\end{array}$ & $\begin{array}{l}\text { Fernández de la Cigoña, 1994; Camiñas, } 2002 \\
\text { Fernández de la Cigoña, 1994; Camiñas, } 2002 \\
\text { Pérea et al., 2001; Camiñas, } 2002 \\
\text { Camiñas, } 2002 \\
\text { Camiñas, } 2002 \\
\text { Camiñas, } 2002 \\
\text { Camiñas, } 2002 \\
\text { Tomás and Raga, } 2008 \\
\text { present study } \\
\text { present study }\end{array}$ \\
\hline
\end{tabular}

* Presence mentioned without specifying concrete sighting or stranding date; ${ }^{* *}$ Presented five lateral scutes instead of four; (M) Mediterranean; (A) Atlantic; (ns) exact location not specified.

ened status, a high number of marine turtles are incidentally caught every year in the western Mediterranean (Álvarez de Quevedo et al., 2010; Carreras and Tomás, 2010) and in the Atlantic Spanish waters (Calabuig and LiriaLoza, 2007; Calabuig et al., 2007). This threat is known also to affect these scarce species, since most records have shown interactions with fisheries (references on table 1, present study). However, we do not know which populations will be impacted by this interaction. This is especially relevant for the green turtle, as there are many putative RMUs of origin within the Mediterranean and at both sides of the Atlantic Ocean (Wallace et al., 2010), with very different conservation status among them, with the Mediterranean RMU being considered to deserve the highest priority for conservation for this species (Wallace et al., 2011).

In the present study we compiled all known records of both the Kemp's ridley and the green turtles along the Spanish coasts and in the western Mediterranean in addition to new records obtained during the last decade. We used ge- 
netic tools to a) confirm the species designation, b) ascertain the origin of the individuals, and c) discuss the conservation implications of our results considering the interaction of turtles reported with local threats and the population of origin.

\section{Materials and methods}

All the marine turtles considered in the present study were found as strandings at beaches or were captured incidentally by fisheries in Spanish coastal waters. Injured or dead marine turtles arrived all year round to the different rescue centres scattered along the coastline. The personnel of the centres identified the species of all individuals using morphological keys described in the literature (Pritchard and Mortimer, 1999) before rehabilitation or necropsy. Tissue or blood samples (Owens and Ruiz, 1980; Dutton, 1995) were collected from turtles not identified as the common loggerhead sea turtle for genetic analysis and stored in ethanol or at $-20^{\circ} \mathrm{C}$.

DNA was extracted from samples using the QIAamp extraction kit (QIAGEN ${ }^{\circledR}$ ) following the manufacturer's instructions. We amplified a $\sim 740 \mathrm{bp}$ fragment of the mitochondrial DNA (mtDNA) control region using the primers LCM15382 (5'-GCTTAACCCTAAAGCATTGG$\left.3^{\prime}\right)$ and H950 (5'GTCTCGGATTTAGGGGTTT-3') (AbreuGrobois et al., 2006) which included the region previously surveyed for several turtle species (Norman et al., 1994). Our $25 \mu$ l polymerase chain reaction (PCR) included the following: genomic DNA, $1 \times$ PCR Buffer, $2 \mathrm{mM} \mathrm{MgCl}_{2}$, $0.12 \mathrm{mM} \mathrm{dNTP}, 0.2 \mu \mathrm{M}$ of each primer and $0.04 \mathrm{U} / \mu \mathrm{l}$ of Taq polymerase. After an initial 5 min denaturing step $\left(94^{\circ} \mathrm{C}\right)$, our PCR protocol consisted of 35 cycles of the following temperature regime: $1 \mathrm{~min}$ at $94^{\circ} \mathrm{C}$ (denaturing), $1 \mathrm{~min}$ at $52^{\circ} \mathrm{C}$ (annealing) and $90 \mathrm{~s}$ at $72^{\circ} \mathrm{C}$ (extension). In addition, we included a final extension step of $10 \mathrm{~min}$ at $72^{\circ} \mathrm{C}$. Following PCR, we removed single-stranded DNA by digesting $5 \mu \mathrm{l}$ of PCR product with $2 \mu \mathrm{l}$ of a combined Exonuclease I and Shrimp Alkaline Phosphatase solution $\left(\right.$ ExoSAP-IT $\left.^{\circledR}\right)$. The reaction was incubated for $15 \mathrm{~min}$ at $37^{\circ} \mathrm{C}$, followed by $15 \mathrm{~min}$ at $80^{\circ} \mathrm{C}$ to inactivate the two enzymes. We sequenced both forward and reverse strands using the BigDye ${ }^{\mathrm{TM}}$ Primer Cycle Sequencing Kit (Applied Biosystems) run on an automated DNA sequencer (ABI PRISM 3100). For each sequencing reaction, we used $2 \mu 1$ of our PCR product in a $10 \mu \mathrm{l}$ reaction mix under the following conditions: $1 \mathrm{~min}$ denaturing step at $96^{\circ} \mathrm{C}$ followed by 25 cycles consisting of an initial denaturing of $10 \mathrm{~s}$ at $96^{\circ} \mathrm{C}, 5 \mathrm{~s}$ at $50^{\circ} \mathrm{C}$ (annealing) and $4 \mathrm{~min}$ at $60^{\circ} \mathrm{C}$ (extension). Products were purified by ethanol precipitation before entering the sequencer. Sequences were aligned manually using the program BioEdit version 5.0.9 (Hall, 1999) and compared with the haplotypes described for the putative marine turtle species and compiled by the Archie Carr Center for Sea Turtle Research of the University of Florida (ACCSTR; http://accstr.ufl.edu) or in the literature (Bowen et al., 1998; Lara-Ruiz et al., 2006).

The approximated age of the turtles was estimated using the biometric information recorded in the rescue centres and applying growth models developed using skeletochronology for the Kemp's Ridley turtle (Zug et al., 1997; Goshe et al., 2010) and the green turtle (Goshe et al., 2010) using animals found in the Atlantic and the Mexico Gulf coasts of USA. As different populations and individuals in different feeding grounds may have different growth (e.g. Piovano et al., 2011), the esteemed age was considered a rough approximation.

\section{Results}

We obtained samples from a total of 9 Cheloniidae marine turtles other than the loggerhead sea turtle that arrived to the rescue centres from Mediterranean and Atlantic Spanish coasts between 2001 and 2012 (fig. 1, table 2). Based on morphological traits, of these 9 turtles, 7 were identified as green turtles and 1 as a Kemp's ridley turtle. The remaining turtle presented the plastron pores that are typical of the genus Lepidochelys and matched a Kemp's ridley except of that it has a total of 6 costal scutes in each side and 7 vertebrate scutes (fig. 2, table 3), a pattern that can be found in the olive ridley turtle (L. olivacea) (Pritchard and Mortimer, 1999). The Kemp's ridley from the Ebro Delta (East Spain) exhibited the haplotype D, as found in western Atlantic nesting beaches (Bowen et al., 1998) and in the other specimen found in the Spanish Mediterranean analyzed in a previous study (Tomás et al., 2003). The individual with unusual number of central and costal scutes exhibited a new haplotype that matched the 353 bp partial sequence of Kemp's ridley obtained from two hybrids born in Rancho Nuevo, Mexico, and released in Galveston Island, Texas (Barber et al., 2003). As we obtained here the full 460 bp sequence previously used to define haplotypes in these species (Bowen et al., 1998), we named this haplotype as $X$ following the previous nomenclature and we submitted it to the NCBI GeneBank (accession number KC609750). This haplotype is very similar to other Kemp's ridley mtDNA haplotypes (table 4) while differs in more than 20 positions from all known Olive ridley haplotypes (data not shown). Hence it was assumed that this in- 


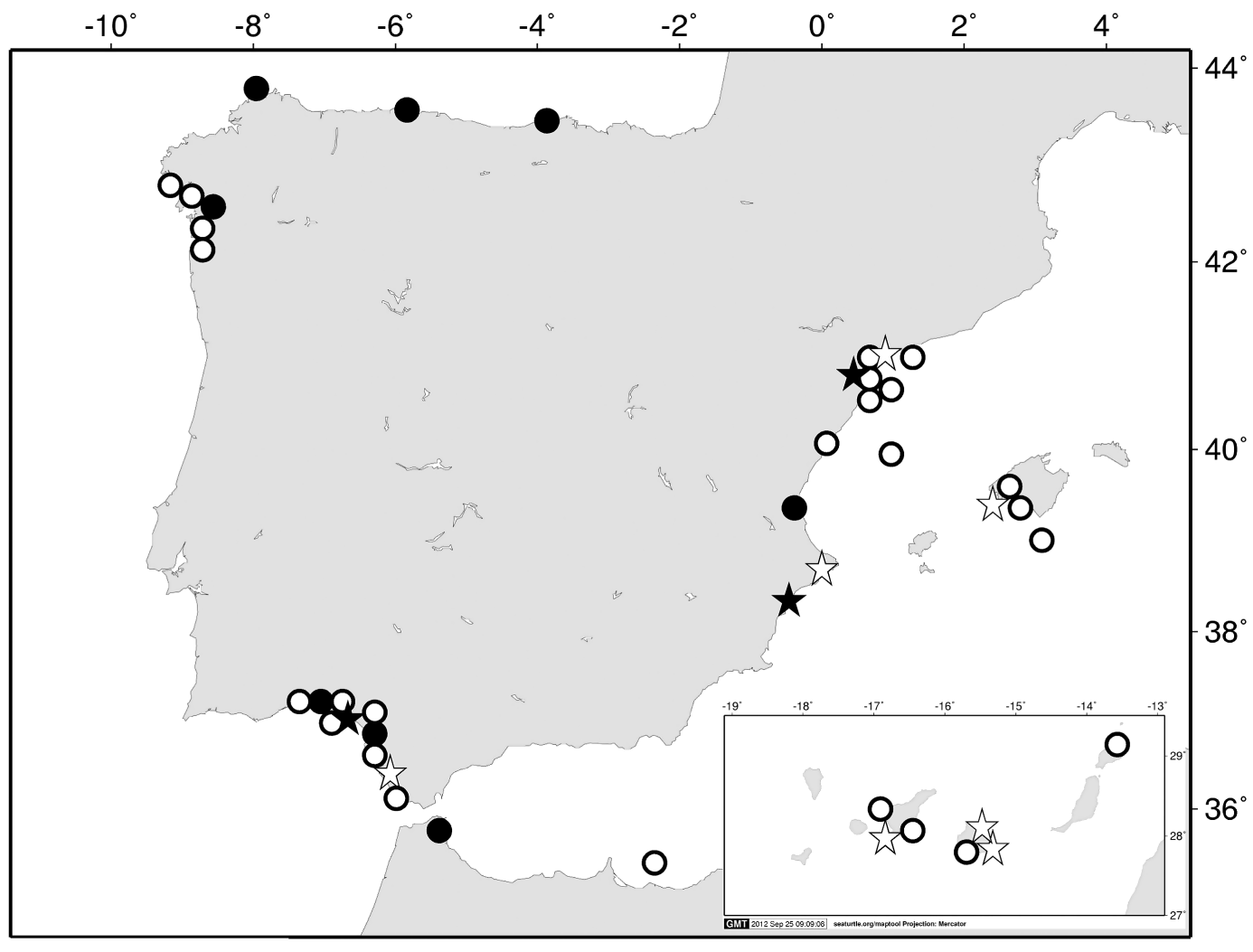

seaturtle.org/maptool Projection: Mercator

Figure 1. Location of all records of the green turtle (white) and the Kemp's ridley turtle (black) in Spanish coasts as detailed in tables 1 and 2. Circles indicate individuals without genetic data (table 1) and stars indicate individuals with genetic data (table 2). The four individuals with exact location not specified (ns) have not been mapped. Inner square shows the Canary Islands, Spanish territory in the eastern Atlantic. Map created using MAPTOOL (SEATURTLE.ORG Maptool, 2002).

Table 2. Basic parameters of green and Kemp's ridley marine turtles sampled in Spanish Mediterranean and Atlantic coasts in the present study. Individuals reported in the literature with mitochondrial DNA (mtDNA) data are also included. SCL: straight carapace length; CCL: curved carapace length.

\begin{tabular}{|c|c|c|c|c|c|c|}
\hline Species & Location & $\begin{array}{l}\text { SCL } \\
(\mathrm{cm})\end{array}$ & Date & $\begin{array}{c}\text { Age } \\
\text { (years) }\end{array}$ & $\begin{array}{l}\text { mtDNA } \\
\text { haplotype }\end{array}$ & Reference \\
\hline \multirow{7}{*}{$\begin{array}{l}\text { C. mydas } \\
\quad(n=7)\end{array}$} & Canary Islands (A) & 47.0 & 03/02/2001 & $13-14$ & CM-A8 & Present study \\
\hline & Canary Islands (A) & 74.0 & $10 / 06 / 2005$ & $21-22$ & CM-A5 & Present study \\
\hline & Canary Islands (A) & 48.0 & $23 / 052005$ & $13-14$ & CM-A5 & Present study \\
\hline & Cadiz Bay (A) & 31.0 & 04/06/2007 & $8-9$ & CM-A8 & Present study \\
\hline & Ebro Delta (M) & 41.0 & $21 / 12 / 2009$ & $10-11$ & CM-A 8 & Present study \\
\hline & Valencia (M) & $39.1^{*}$ & $28 / 08 / 2010$ & $10-11$ & CM-A 8 & Present study \\
\hline & Mallorca Island (M) & 32.5 & 09/06/2012 & $8-9$ & CM-A8 & Present study \\
\hline \multirow{3}{*}{$\begin{array}{l}\text { L. kempii } \\
\qquad(n=3)\end{array}$} & Santa Pola (M) & 29.5 & $15 / 10 / 2001$ & $3-4$ & $\mathrm{D}$ & Tomás et al., 2003 \\
\hline & Ebro Delta (M) & 31.5 & $26 / 09 / 2002$ & $3-4$ & $\mathrm{D}$ & Present study \\
\hline & Cadiz Bay (A) & 23.0 & 05/09/2005 & $1-2$ & $X$ & Present study \\
\hline
\end{tabular}

* Originally measured as CCL and converted to SCL using the equation SCL $=0.9426 \mathrm{CCL}-0.0515$ (Goshe et al., 2010); (M) Mediterranean; (A) Atlantic. 


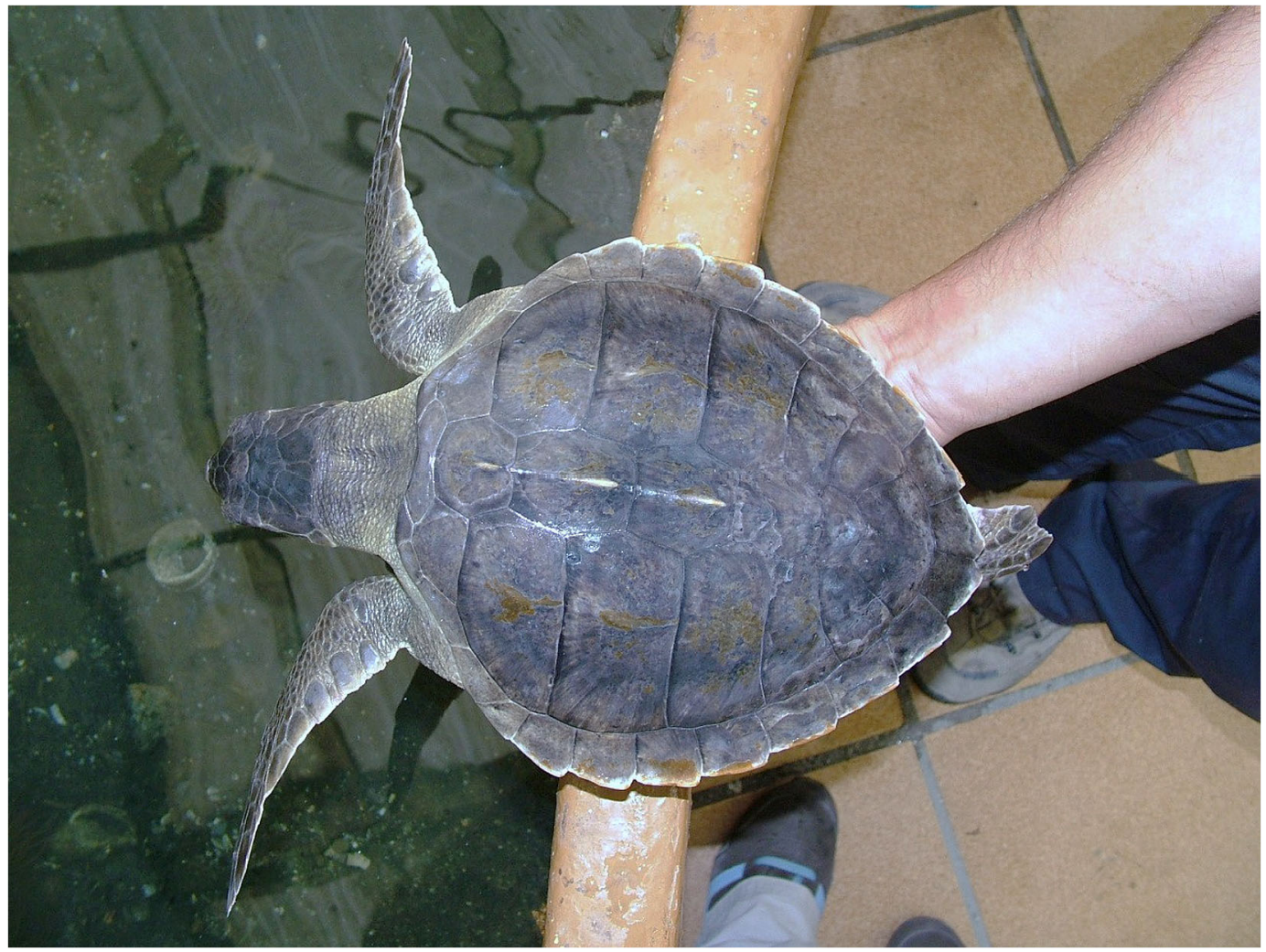

Figure 2. Dorsal view of the Lepidochelys kempii individual found in the Cadiz Bay (05/09/2005) showing an abnormal number of seven dorsal and six costal scutes. This figure is published in colour in the online version.

dividual was a Kemp's ridley turtle with supernumerary scutes, a rare abnormality in Kemp's ridley turtles (Mast and Carr, 1989), and carrying a new haplotype. Green turtles sampled in all locations exhibited the CM-A8 haplotype (table 2), that is exclusive from the Atlantic and the south western Indian oceans (fig. 3), being the most frequent haplotype in African nesting populations (Formia et al., 2006). Furthermore, two samples from the Canary Islands exhibited the CM-A5 which is the most frequent haplotype in Aves Island (Venezuela) and Surinam, but also found at low frequency in Mexico (Atlantic coast) and São Tome (Encalada et al., 1996; Formia et al., 2006). All but one individuals were classified as juveniles (table 2): juvenile green turtles aged 8-14 and Kemp's ridley $1-5$. The remaining green turtle was an adult aged 21-22 years. The ages of the Kemp's ridley turtles were similar to the estimated for other records in the Mediterranean (Brongersma and Carr, 1983; Tomás et al., 2003; Oliver and Pigno, 2005; Tomás and Raga, 2008; Insacco and Spadola, 2010).

\section{Discussion}

Including our new records, we compiled data from 33 green turtles (C. mydas) and 13 Kemp's ridley turtles (L. kempii) in the Spanish coastal waters. The genetic results of one of the analysed Kemp's ridley turtles (Ebro Delta) matched previous findings (Tomás et al., 2003) that demonstrated the entrance of this species in the Mediterranean through the Gibraltar Straits. Furthermore, the use of genetic tools was essential for the species determination in the other case (Cadiz Bay). Traditional classification of marine turtles is usually based on morphological characters as colour, shape, size or pat- 
Table 3. Comparative table between the two Lepidochelys sp. individuals sampled in the present study and the standard values of L. kempii and L. olivacea. SCL: straight carapace length; SCW: straight carapace width; CCL: curved carapace length; CCW: curved carapace width.

\begin{tabular}{|c|c|c|c|c|}
\hline & Cadiz Bay & Ebro Delta & L. kempii* & L. olivacea* \\
\hline $\mathrm{SCL}(\mathrm{cm})$ & 23.0 & 31.5 & $\max .72$ & $\max .74^{* * *}$ \\
\hline $\mathrm{SCW}(\mathrm{cm})$ & 23.0 & 29.5 & & \\
\hline CCL (cm) & 24.5 & 30.0 & & $\max .78^{* * *}$ \\
\hline $\mathrm{CCW}(\mathrm{cm})$ & 26.0 & 31.0 & & \\
\hline Weight (kg) & 2.3 & 4.4 & $35-50$ (adult) & $35-50$ (adult) \\
\hline Estimated age & $1-2$ & $3-4$ & & \\
\hline Captured & 05/09/2005 & $26 / 09 / 2002$ & & \\
\hline Costal scutes & 6 & 5 & 5 & $5-9$ \\
\hline Vertebral scutes & 7 & 5 & 5 & $5-9$ \\
\hline Claws & 2 & 2 & 2 but may lose 1 & 2 but may lose 1 \\
\hline Dorsal coloration & grey & grey & $\begin{array}{l}\text { grey (juveniles) light olive } \\
\text { green (adults) }\end{array}$ & $\begin{array}{l}\text { grey (juveniles) dark olive } \\
\text { green (adults) }\end{array}$ \\
\hline Ventral coloration & white & white & $\begin{array}{l}\text { white (juveniles) yellow } \\
\text { (adults) }\end{array}$ & $\begin{array}{l}\text { white (juveniles) cream } \\
\text { yellow (adults) }\end{array}$ \\
\hline Plastron pores & yes & yes & yes & yes \\
\hline Haplotype & $\mathrm{X}$ & $\mathrm{D}$ & $\mathrm{A}-\mathrm{D}^{* *}$ & $\mathrm{E}-\mathrm{W}^{* *}$ \\
\hline Nesting areas & & & Mexico Gulf western USA & $\begin{array}{l}\text { Pacific Ocean Indic } \\
\text { Ocean } \\
\text { South Atlantic }\end{array}$ \\
\hline
\end{tabular}

\footnotetext{
* Biometric data from (Pritchard and Mortimer, 1999).

** Haplotypes described in (Bowen et al., 1998; Lopez-Castro and Rocha-Olivares, 2005).

*** From (Tomás et al., 2001).
}

Table 4. Polymorphic sites (and their position) found in a $460 \mathrm{bp}$ fragment of the mitochondrial Control Region of 2 stranded L. kempii individuals, compared to the known haplotypes for this species. $n=$ total number of samples with this haplotypes; GAB: GenBank Accession number.

\begin{tabular}{lllllllll}
\hline Haplotype & 1 & 1 & 1 & 3 & 3 & $n$ & GAB & Reference \\
& 2 & 5 & 7 & 4 & 8 & & & \\
\hline A & 1 & 4 & 0 & 4 & 6 & & & \\
B & T & C & A & C & G & 2 & AF051777.1 & Bowen et al., 1998 \\
C & T & A & A & C & A & 1 & Derived from A & Bowen et al., 1998 \\
D & C & C & G & T & A & 1 & Derived from A & Bowen et al., 1998 \\
X & C & C & A & C & A & 7 & Derived from A & Bowen et al., 1998; Tomás et al., 2003; present study \\
\hline
\end{tabular}

tern of scutes of carapace and head. This set of characters generates very valuable keys for those researchers that are unfamiliar with the species (Pritchard and Mortimer, 1999). However, sometimes those characters lead to misclassification due to alterations in the embryonic development or by trauma at the earliest stages of the life cycle that may produce the presence of more or less scutes than usual (Mast and Carr, 1989). In this case there was no consensus of the species identification of the animal using morphological traits (table 3, fig. 2) but genetic tools helped to identify the individual as a Kemp's ridley turtle. Despite the fact that the haplotype found was not previously discovered, apart from the partial sequence of the two animals from Rancho Nuevo (Mexico) released in Galveston Island (Texas), its close proximity to the other Kemp's ridley haplotypes (one single substitution to the closest haplotype) relative to the olive ridley haplotypes (more than 20 substitutions to the closest haplotype) allowed to identify the haplotype as being from the Kemp's rid- 


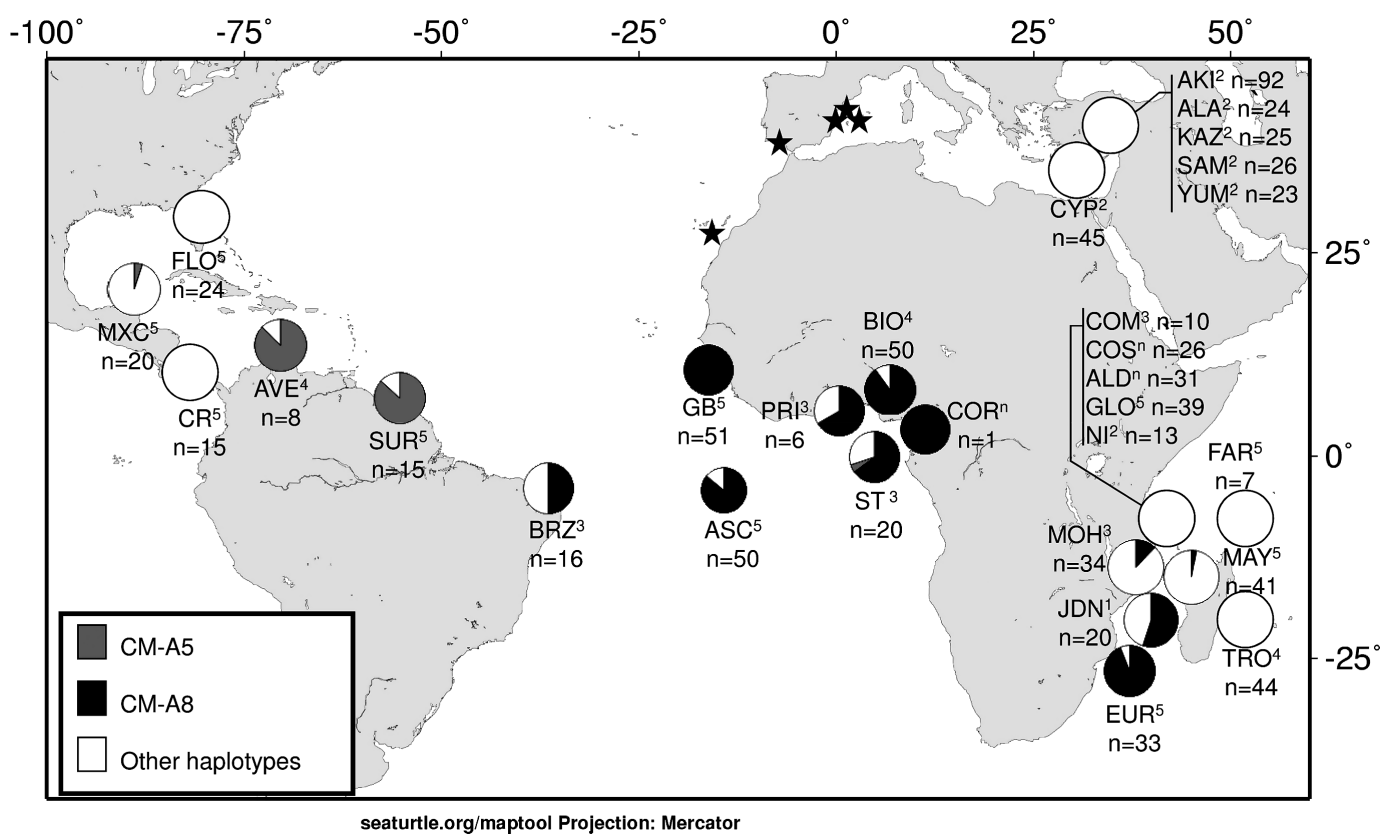

Figure 3. Frequency of the green turtle CM-A 8 and CM-A5 haplotypes in Mediterranean, Atlantic and Indic nesting populations. Each pie graph indicates the relative frequency of the haplotypes in a green turtle nesting populations $(n=$ sample size). The five sampling sites of all seven green turtles with mtDNA data from this study (table 2) are represented by the black stars. Nesting population size are coded as superscripts for each population as $1:<25$ females/year; 2 : 25-100 females/year; 3: 100-500 females/year; 4: 500-1000 females/year; 5: >1000 females/year and n: not quantified (data from DiMatteo et al., 2009). FLO: Florida; MXC: Mexico; CR: Costa Rica; AVE: Aves; SUR: Surinam; BRZ: Brazil (Encalada et al., 1996); ASC: Ascension Island; GB: Guinea Bissau; PRI: Principe; BIO: Bioko; COR: Corisco; ST: São Tome; COM: Comoros (Formia et al., 2006); EUR: Europa; JDN: Juan de Nova; TRO: Tromelin; MOH: Mohéli; MAY: Mayotte; FAR: Farquhar; COS: Cosmoledo; ALD: Aldabra; GLO: Glorieuses; NI: Nosy Iranja (Bourjea et al., 2007); AKY: Akyatan; ALA: Alata; KAZ: Kazanli; SAM: Samandağ; YUM; Yumurtalik (Bagda et al., 2012); CYP: Cyprus (Encalada et al., 1996; Bagda et al., 2012). The Indic populations of COM, COS, ALD, GLO and NI and the Turkish populations of AKY, ALA, KAZ, SAM and YUM are represented each one by a single pie graph due to the geographical proximity between them and considering that CM-A8 and CM-A5 were absent from these populations. Map created using MAPTOOL (SEATURTLE.ORG Maptool, 2002).

ley. Future studies are needed to reveal whether this orphan haplotype corresponds to a nonsampled nesting area, like Florida (Johnson et al., 1999), or if has not been found in one of the sampled nesting beaches by chance due to a low frequency of occurrence, like in Texas or Mexico, where these individuals were born and released respectively. However, an alternative explanation of the scute variation found in this individual is that could be the result of a hybridisation between a Kemp's ridley female and a male from other species. The hybridisation of Kemp's ridley with the loggerhead sea turtle is not unprecedented (Barber et al., 2003) but both species have the same number of scutes and thus the differences of the hybrids rely in coloration and shape, that is not the case in our individual. Only an hybridisation with an olive Ridley could explain the extra number of scutes, an unlikely possibility considering the very different distribution of both species and the inexistence of common feeding areas (table 3). Thus, the analysis of nuclear markers is needed to completely discard this remote possibility (Bowen and Karl, 2007; Vilaca et al., 2012). It is worth to mention that this putative hybridisation would have no consequences for the maternally inherited mtDNA, and thus the question of the orphan haplotype remains unanswered. Considering our result, we strongly rec- 
ommend the use of genetic markers for the identification of a rare species in an area different from its known range of distribution, not only when morphological traits are insufficient for species assignation or when some abnormality is present.

Three different non exclusive theories may explain why the Kemp's ridley turtle has not been reported in the study area until very recent decades in comparison to the green turtle. The first one is that the research and rescue effort in the area has significantly increased during this period (Carreras and Tomás, 2010). This would have produced, not only a greater chance to detect a stranded turtle, but also a better species determination skill of the personnel handling these individuals (Tomás and Raga, 2008; Insacco and Spadola, 2010). It is remarkable to read the description of the abnormal green turtle found around Columbretes Islands in 1899 (Boscá, 1916; Tomás and Raga, 2008) with the presence of 5 costal scutes instead of 4 . The author concluded, using 'secondary characters' that the individual should necessarily have been a green turtle instead of a loggerhead, but unfortunately he did not explain what these secondary characters were. The Kemp's ridley was described as a new species only a few years before (Garman, 1880) and described literally as ' $a$ cross between the green and loggerhead' since the coloration of the Kemp's ridley is more similar to a juvenile green turtle but it has the costal scute pattern of the loggerhead turtle. Hence, the 1899 record could have been a misidentified Kemp's ridley instead of a green turtle. Although this explanation would explain the lack of records during the first half of the $20^{\text {th }}$ century, it hardly explains the lack of records during the second half of the $20^{\text {th }}$ century, were the rescue centres and research groups started to study and identify marine turtles in the area (Carreras and Tomás, 2010). As a second explanation, Kemp's ridley distribution of the oceanic stage is highly sensitive to ocean circulation (Putman et al., 2010) and cohorts under different conditions have very different dis- tribution patterns (Putman et al., 2013), thus any variation in the ocean circulation during these decades probably affected the chance of turtles arriving at Spanish coasts. The third possible explanation to the increase of Kemp's ridley reports, specially for the last decades, is the fact that nesting populations of this species were reduced up to a $1 \%$ of the original populations during the second half of the $20^{\text {th }}$ century, due to human interaction, and partially recovered during the first decade of the $21^{\text {th }}$ century (National Marine Fisheries Service et al., 2011). This significant recent population growth could resulted in an increase of the records in the western Mediterranean during the last decades that contrast to an absence of records during the second half of the $20^{\text {th }}$ century, a pattern that has also been suggested for records in north western European coasts (Witt et al., 2007).

Our results also revealed that green turtles from eastern and western Atlantic nesting populations arrive at Spanish waters, not only at the feeding grounds located in the Atlantic ocean but also at those within the Mediterranean sea. This demonstrates for the first time the presence of Atlantic green turtles within the Mediterranean, and although the exact RMU of origin within the Atlantic could not be determined, haplotype composition suggests that these turtles could be originated in the east, the south west, the south central or even the south Caribbean Atlantic RMUs (Wallace et al., 2010). Although no specific studies have been conducted on the putative routes followed by the Atlantic green turtles that feed on the Spanish coasts, previous studies have described the migratory routes for loggerheads (Bolten et al., 1998; Carreras et al., 2006; Monzon-Arguello et al., 2009; Monzon-Arguello et al., 2012) and a general pattern was described for green turtles in the whole Atlantic area (Monzon-Arguello et al., 2010). Furthermore, several studies focused on the modelling of particle drifting, sometimes in addition to genetic studies, have been used to assess movements and distribution either of the Kemp's ridley turtle (Putman et al., 2010; 
Putman et al., 2013) or the green turtle (Putman and Naro-Maciel, 2013), suggesting a strong influence of oceanographic surface currents and indicating the putative routes from each RMU into the vicinity of the different Spanish feeding grounds. Surprisingly, no green turtle from our sample set exhibited any of the haplotypes found in the closest eastern Mediterranean nesting beaches (Encalada et al., 1996; Bagda et al., 2012).

The green turtle has been catalogued as endangered (IUCN, 2011) with a proposal to list the Mediterranean populations critically endangered (Groombridge, 1990) due to their decline as a result of historical harvesting (Sella, 1982), and the Mediterranean RMU is considered the most endangered for this species (Wallace et al., 2011). The conservation status of the Mediterranean green turtle populations has been a matter of discussion (Mrosovsky, 2006a, 2006b; Naro-Maciel and Formia, 2006) with a critical point being the IUCN criteria for an independent classification and therefore the question of whether the Mediterranean nesting populations are isolated from the Atlantic ones. Previous genetic studies have shown that these populations are independent units in terms of the maternally inherited mtDNA (Encalada et al., 1996) and RFLPs (Karl et al., 1992). However, the recent application of biparentally inherited microsatellite markers did not succeed in detecting such differentiation either at intra or inter oceanic level (Roberts et al., 2004). Four non exclusive hypotheses were suggested to explain these results including a) a high level of homoplasy caused by a high mutation rate relative to the length of time separating the two populations, b) too polymorphic markers that produce high heterozigosity within population that overshadow differences between populations, resulting in an underestimation of subdivision, c) low differentiation resolution caused by an insufficient number of markers used (Roden et al., 2013) and d) male mediated gene flow. Male mediated gene flow is thought to occur in marine turtles as a consequence of the ex- istence of shared feeding areas (Bowen et al., 2005). Until the research presented here there was no evidence of Atlantic individuals coming into the Mediterranean that could link Atlantic and Mediterranean green turtle populations. Whether the presence of Atlantic individuals within the Mediterranean could prevent the isolation of Mediterranean green nesting populations is an issue that requires further testing with nuclear markers, but several lines of evidence suggest an isolation scenario. The first line of evidence is that no eastern Mediterranean green turtle was detected within our samples or in any Atlantic foraging grounds (MonzonArguello et al., 2010; Proietti et al., 2012), and particle modelling studies indicated that particles originated in the eastern Mediterranean are not able to drift passively into the western basin (Putman and Naro-Maciel, 2013). These results suggest that turtles from the two different origins may not share foraging areas despite both being present within the Mediterranean Sea and Mediterranean green turtles being known to arrive as far as Libya or Tunisia (Godley et al., 2002; Rees et al., 2008). Furthermore, all turtles that were measured within the western Mediterranean or Peninsular Atlantic coasts were immature and their abundance was very low. Finally, despite the loggerhead sea turtle being much more abundant in the area and individuals of this species from Atlantic and Mediterranean rookeries using the same feeding grounds in the western Mediterranean, gene flow between these nesting areas does not exist in this species (Carreras et al., 2011).

Independently of the possibility of male mediated gene flow between Atlantic and Mediterranean green sea turtles, other conservation questions arise from our results for both the green and the Kemp's ridley marine turtles. Serious threats to these animals occur in Spanish Mediterranean waters (Carreras and Tomás, 2010), specially the incidental capture of individuals by fisheries, as longline (Camiñas et al., 2006; Baez et al., 2010), trammel net (Carreras et al., 2004) or bottom trawling (Álvarez 
de Quevedo et al., 2010). This interaction is estimated to produce an annual mortality of $27 \%$ in the whole western Mediterranean (Casale et al., 2007). Furthermore, the entrance into the Mediterranean is asymmetrical as the Gibraltar straits seems to be a barrier for the smaller turtles leaving the Mediterranean (Revelles et al., 2007) hence possibly forcing them to stay for several years within the area under the fisheriesinduced mortality. These fisheries are known to interact with the green and the Kemp's ridley sea turtles in other areas of the world (Hays et al., 2003; Lewison et al., 2003; National Marine Fisheries Service et al., 2011), and hence might be also affected by the same threats than the loggerheads, since all but one of the nine individuals arrived to the rescue centres as a consequence of interaction with human activities, like in other records (e.g. Tomás et al., 2003). Whether these animals would be able to return or not to the Atlantic populations of origin regardless of human interactions is a question that remains unanswered, but the other marine turtle species that use these foraging areas, the loggerhead turtle, is able to do this return migration (e.g. Eckert et al., 2008). Our results suggest that the western Mediterranean may act as a dead end for individuals of these endangered species, that would affect the RMUs that originated them (present study, Wallace et al., 2010). For these reasons, we recommend that both species should be considered in Spanish marine turtle conservation and management plans.

Acknowledgements. The authors want to acknowledge to the members of the Marine Zoology Unit of the Cavanilles Institute of the University of Valencia, the staff of 'La Granja de El Saler' rescue centre of the 'Oceanogràfic' of Valencia, the Marine Animal Rescue Center (CRAM) of Catalonia, the 'Aula del Mar' of Málaga and the 'Centro de Recuperación de Fauna Silvestre de Tafira'. We also want to acknowledge the support of the 'Conselleria de Infraestructuras, Territorio y Medio Ambiente' of the Valencia Government (Generalitat Valenciana) and the support of the 'Dirección General de Medio Natural de Andalucía'. C. Carreras is supported by the 'Beatriu de Pinós' programme of the 'Departament d'Universitats, Recerca i Societat de la Informació de la Generalitat de Catalunya'. J. Tomás and P. Gozalbes are supported by project Prometeo/2011/40 of 'Conselleria de Educació' (Generalitat Valenciana) and project CGL2011-30413 of the Spanish Ministry of Economy and Competitiveness. The manuscript was improved by the input of two anonymous reviewers.

\section{References}

Abreu-Grobois, A., Horrocks, J., Formia, A., Leroux, R., Velez-Zuazo, X., Dutton, P.H., Soares, L., Meylan, A., Browne, D. (2006): New mtDNA dloop primers which work for a variety of marine turtle species may increase the resolution capacity of mixed stock analysis. In: 26th Annual Symposium on Sea Turtle Biology and Conservation, p. 179. Frick, M.G., Panagopoulou, A., Rees, A., Williams, K.L., Eds, Crete, Greece.

Álvarez de Quevedo, I., Cardona, L., De Haro, A., Pubill, E., Aguilar, A. (2010): Sources of bycatch of loggerhead sea turtles in the western Mediterranean other than drifting longlines. Ices Journal of Marine Science 67: 677-685.

Baez, J.C., Real, R., Macias, D., de la Serna, J.M., Bellido, J.J., Camiñas, J.A. (2010): Captures of swordfish Xiphias gladius (Linnaeus 1758) and loggerhead sea turtles Caretta caretta (Linnaeus 1758) associated with different bait combinations in the Western Mediterranean surface longline fishery. J. Appl. Ichthyol. 26: 126-127.

Bagda, E., Bardakci, F., Turkozan, O. (2012): Lower genetic structuring in mitochondrial DNA than nuclear DNA among the nesting colonies of green turtles (Chelonia mydas) in the Mediterranean. Biochem. Syst. Ecol. 43: 192-199.

Barber, R.C., Fontaine, C.T., Flanagan, J.P., Louis, E.E., Jr. (2003): Natural hybridization between a Kemp's ridley (Lepidochelys kempii) and loggerhead sea turtle (Caretta caretta) confirmed by molecular analysis. Chelonian Conserv. Bi. 4: 701-704.

Barcelo, F. (1876): Nuevos apuntes para la fauna balear: catálogo de los reptiles y de los moluscos terrestres y de agua dulce observados en las islas Baleares. Museo Balear de Historia y Literatura, Ciencias y Artes 3: 201210.

Bertolero, A. (2003): Varamientos y capturas marinas en los alrededores del Delta del Ebro (NE España) entre los años 1984 y 2001. Revista Española de Herpetología 17: 39-53.

Bolten, A.B., Bjorndal, K.A., Martins, H.R., Dellinger, T., Biscoito, M.J., Encalada, S.E., Bowen, B.W. (1998): Transatlantic developmental migrations of loggerhead sea turtles demonstrated by mtDNA sequence analysis. Ecol. Appl. 8: 1-7.

Boscá, E. (1877): Catálogo de los reptiles y anfibios observados en España, Portugal e Islas Baleares. Anales de la Sociedad Española de Historia Natural 6: 39-69.

Boscá, E. (1916): Individuo anómalo de Chelonia mydas (L.) en el Mediterráneo. Boletín de la Real Sociedad Española de Historia Natural 16: 446-448. 
Bourjea, J., Lapegue, S., Gagnevin, L., Broderick, D., Mortimer, J.A., Ciccione, S., Roos, D., Taquet, C., Grizel, H. (2007): Phylogeography of the green turtle, Chelonia mydas, in the Southwest Indian Ocean. Mol. Ecol. 16: 175-186.

Bowen, B.W., Karl, S.A. (1997): Population genetics, phylogeography, and molecular evolution. In: The Biology of Sea Turtles, p. 29-50. Lutz, P.L., Musick, J.A., Eds, CRC Press, Boca Raton.

Bowen, B.W., Clark, A.M., Abreu-Grobois, F.A., Chaves, A., Reichart, H.A., Ferl, R.J. (1998): Global phylogeography of the ridley sea turtles (Lepidochelys spp.) as inferred from mitochondrial DNA sequences. Genetica (Dordrecht) 101: 179-189.

Bowen, B.W., Bass, A.L., Soares, L., Toonen, R.J. (2005): Conservation implications of complex population structure: lessons from the loggerhead turtle (Caretta caretta). Mol. Ecol. 14: 2389-2402.

Bowen, B.W., Karl, S.A. (2007): Population genetics and phylogeography of sea turtles. Mol. Ecol. 16: 48864907.

Brongersma, L.D. (1967): Guide for the identification of stranded turtles on British coasts. Publication of the British Museum (Natural History): 1-23.

Brongersma, L.D. (1972): European Atlantic turtles. Zoologische Verhandelingen 121: 1-317.

Brongersma, L.D., Carr, A.F. (1983): Lepidochelys kempi (Garman) from Malta. Proceedings of the Koninklijke Nederlandse Akademie Van Wetenschappen Series CBiological and Medical Sciences 86: 445-454.

Calabuig, P., Liria-Loza, A. (2007): Recovery of marine turtles injured in the waters of the Canary island archipelago (Spain) between 1998 and 2003. In: Marine Turtles. Recovery of Extinct Populations, p. 113123. López-Jurado, L.F., Liria-Loza, A., Eds, Instituto Canario de Ciencias Marinas, Las Palmas, Spain.

Calabuig, P., Liria-Loza, A., López-Jurado, L.F. (2007): Sea turtles recovered at the Wild Fauna Recovery Center in Gran Canaria (Canary Islands, Spain). In: Proceedings of the 24th Annual Sea Turtle Symposium, p. 76. NMFS-SEFSC-567, N.T.M., Ed., San José, Costa Rica, NOAA.

Camiñas, J.A. (2002): Estatus y conservación de las Tortugas Marinas en España. In: Atlas y Libro Rojo de los Anfibios y Reptiles de España, p. 345-380. Pleguezuelos, J.M., Márquez, R., Liziana, M., Eds, Dirección General de Conservación de la Naturaleza-Asociación Herpetológica Española, Madrid.

Camiñas, J.A., Baez, J.C., Valeiras, X., Real, R. (2006): Differential loggerhead by-catch and direct mortality due to surface longlines according to boat strata and gear type. Scientia Marina 70: 661-665.

Carreras, C., Cardona, L., Aguilar, A. (2004): Incidental catch of the loggerhead turtle Caretta caretta off the Balearic Islands (western Mediterranean). Biol. Conserv. 117: 321-329.

Carreras, C., Pont, S., Maffucci, F., Pascual, M., Barcelo, A., Bentivegna, F., Cardona, L., Alegre, F., SanFelix, M., Fernandez, G., Aguilar, A. (2006): Genetic structuring of immature loggerhead sea turtles (Caretta caretta) in the Mediterranean Sea reflects water circulation patterns. Mar. Biol. 149: 1269-1279.
Carreras, C., Tomás, J. (2010): Spain. In: Sea Turtles in the Mediterranean: Distribution, Threats and Conservation Priorities, p. 205-232. Casale, P., Margaritoulis, D., Eds, IUCN, Gland, Switzerland.

Carreras, C., Pascual, M., Cardona, L., Marco, A., Bellido, J.J., Castillo, J.J., Tomás, J., Raga, J.A., Sanfelix, M., Fernandez, G., Aguilar, A. (2011): Living together but remaining apart: Atlantic and Mediterranean loggerhead sea turtles (Caretta caretta) in shared feeding grounds. J. Hered. 102: 666-677.

Casale, P., Mazaris, A.D., Freggi, D., Basso, R., Argano, R. (2007): Survival probabilities of loggerhead sea turtles (Caretta caretta) estimated from capture-mark-recapture data in the Mediterranean Sea. Scientia Marina 71: 365372.

Casale, P., Margaritoulis, D. (2010): Sea Turtles in the Mediterranean: Distribution, Threats and Conservation Priorities. IUCN/SSC Marine Turtle Specialist Group, Gland, Switzerland.

DiMatteo, A.D., Fujioka, E., Wallace, B.P., Hutchinson, B.J., Cleary, J., Halpin, P.N. (2009): SWOT Database Online. Available at http://seamap.env.duke.edu/swot.

Dutton, P.H. (1995): Methods for collection and preservation of samples for sea turtle genetic studies. In: Proceedings of the International Symposium on Sea Turtle Conservation Genetics, p. 17-24. Bowen, B.W., Witzell, W.N., Eds, Springfield, Virginia, NOAA Technical Memorandum NMFS-SEFSC 396. National Technical Information Service.

Eckert, S.A., Moore, J.E., Dunn, D.C., van Buiten, R.S., Eckert, K.L., Halpin, P.N. (2008): Modeling loggerhead turtle movement in the Mediterranean: Importance of body size and oceanography. Ecol. Appl. 18: 290-308.

Encalada, S.E., Lahanas, P.N., Bjorndal, K.A., Bolten, A.B., Miyamoto, M.M., Bowen, B.W. (1996): Phylogeography and population structure of the Atlantic and Mediterranean green turtle Chelonia mydas: A mitochondrial DNA control region sequence assessment. Mol. Ecol. 5: 473-483.

Fernández de la Cigoña, E. (1994): Esta fauna nosa Vigo.

Formia, A., Godley, B.J., Dontaine, J.F., Bruford, M.W. (2006): Mitochondrial DNA diversity and phylogeography of endangered green turtle (Chelonia mydas) populations in Africa. Conserv. Genet. 7: 353-369.

Garman, S. (1880): On certain species of Chelonioidae. Bulletin of the Museum of Comparative Zoology 6: 123126.

Godley, B.J., Richardson, S., Broderick, A.C., Coyne, M.S., Glen, F., Hays, G.C. (2002): Long-term satellite telemetry of the movements and habitat utilisation by green turtles in the Mediterranean. Ecography 25: 352-362.

Goshe, L.R., Avens, L., Scharf, F.S., Southwood, A.L. (2010): Estimation of age at maturation and growth of Atlantic green turtles (Chelonia mydas) using skeletochronology. Mar. Biol. 157: 1725-1740.

Groombridge, B. (1990): Marine turtles in the Mediterranean: distribution, population status, conservation. Nature and Environment Series (Council of Europe) 48: 198. 
Hall, T.A. (1999): BioEdit: a user-friendly biological sequence alignment editor and analysis program for Windows 95/98/NT. Nucleic Acids Symposium Series 41: 95-98.

Hays, G.C., Broderick, A.C., Godley, B.J., Luschi, P., Nichois, W.J. (2003): Satellite telemetry suggests high levels of fishing-induced mortality in marine turtles. Mar. Ecol.-Prog. Ser. 262: 305-309.

Insacco, G., Spadola, F. (2010): First record of Kemp's ridley sea turtle, Lepidochelys kempii (Garman, 1880) (Cheloniidae), from the Italian waters (Mediterranean Sea). Acta Herpetol. 5: 113-117.

IUCN (2011): Red list of threatened species. Version 2011.2. http://www.iucnredlist.org/.

Johnson, S.A., Bass, A.L., Libert, B., Marshall, M., Fulk, D. (1999): Kemp's ridley (Lepidochelys kempi) nesting in Florida. Florida Scientist 62: 194-204.

Karl, S.A., Bowen, B.W., Avise, J.C. (1992): Global population genetic structure and male-mediated gne flow in the green turtle (Chelonia mydas)-RFLP analyses of anonimous nuclear loci. Genetics 131: 163-173.

Lara-Ruiz, P., Lopez, G.G., Santos, F.R., Soares, L.S. (2006): Extensive hybridization in hawksbill turtles (Eretmochelys imbricata) nesting in Brazil revealed by mtDNA analyses. Conserv. Genet. 7: 773-781.

Laurent, L., Lescure, J., Excoffier, L., Bowen, B.W., Domingo, M., Hadjichristophorou, M., Kornaraky, L., Trabucht, G. (1993): Genetic studies of relationships between Mediterranean and Atlantic populations of loggerhead turtle Caretta caretta with a mitochondrial marker. Comptes Rendus de l'Académie des Sciences de la Vie. Sciences de la Vie, Paris 316: 1233-1239.

Laurent, L., Casale, P., Bradai, M.N., Godley, B.J., Gerosa, G., Broderick, A.C., Schroth, W., Schierwater, B., Levy, A.M., Freggi, D., Abd El-Mawla, E.M., Hadoud, D.A., Gomati, H.E., Domingo, M., Hadjichristophorou, M., Kornaraky, L., Demirayak, F., Gautier, C. (1998): Molecular resolution of marine turtle stock composition in fishery bycatch: a case study in the Mediterranean. Mol. Ecol. 7: 1529-1542.

Lewison, R.L., Crowder, L.B., Shaver, D.J. (2003): The impact of turtle excluder devices and fisheries closures on loggerhead and Kemp's ridley strandings in the western Gulf of Mexico. Conserv. Biol. 17: 1089-1097.

Lohmann, K.J., Witherington, B.E., Lohmann, C.M.F., Salmon, M. (1997): Orientation, navigation and natal beach homing in sea turtles. In: The Biology of Sea Turtles, p. 107-136. Lutz, P.L., Musick, J.A., Eds, CRC Press, Boca Raton.

Lopez-Castro, M.C., Rocha-Olivares, A. (2005): The panmixia paradigm of eastern Pacific olive ridley turtles revised: consequences for their conservation and evolutionary biology. Mol. Ecol. 14: 3325-3334.

López-Jurado, L.F., Liria, A. (2007): Marine Turtles. Recovery of Extinct Populations. Instituto Canario de Ciéncias Marinas, Las Palmas de Gran Canaria (Spain).

López Seoane, V. (1877): Reptiles y anfibios de Galicia. Anales de la Sociedad Española de Historia Natural 6: 349-358.
Loveridge, A., Williams, E. (1957): Revision of the African tortoises and turtles of the suborder Cryptodira. Bulletin of the Museum of Comparative Zoology 115: 163-557.

Machado, A. (1859): Erpetología hispalensis, seu catalogus methudicus reptilium et amphibiorum in provincia hispalensi viventium. MDCCLIX. Real Academia de Ciencias Exactas, Físicas y Naturales IV (Ciencias Naturales): 561-573.

Mast, R.B., Carr, J.L. (1989): Carapacial scute variation in Kemp's Ridley sea turtle (Lepidochelys kempi) hatchlings and juveniles.

Miller, J.D. (1997): Reproduction in sea turtles. In: The Biology of Sea Turtles, p. 51-82. Lutz, P.L., Musick, J.A., Eds, CRC Press, Boca Raton.

Monzon-Arguello, C., Rico, C., Carreras, C., Calabuig, P., Marco, A., Lopez-Jurado, L.F. (2009): Variation in spatial distribution of juvenile loggerhead turtles in the eastern Atlantic and western Mediterranean Sea. J. Exp. Mar. Biol. Ecol. 373: 79-86.

Monzon-Arguello, C., Lopez-Jurado, L.F., Rico, C., Marco, A., Lopez, P., Hays, G.C., Lee, P.L.M. (2010): Evidence from genetic and Lagrangian drifter data for transatlantic transport of small juvenile green turtles. J. Biogeogr. 37: 1752-1766.

Monzon-Arguello, C., Dell'Amico, F., Moriniere, P., Marco, A., Lopez-Jurado, L.F., Hays, G.C., Scott, R., Marsh, R., Lee, P.L.M. (2012): Lost at sea: genetic, oceanographic and meteorological evidence for stormforced dispersal. J. R. Soc. Interface 9: 1725-1732.

Moritz, C. (1994): Defining evolutionarily significant units for conservation. Trends Ecol. Evol. 9: 373-375.

Mrosovsky, N. (2006a): Commentary: What is a subpopulation? Marine Turtle Newsletter 114: 8.

Mrosovsky, N. (2006b): Does the Mediterranean green turtle exist? Marine Turtle Newsletter 111: 1-2.

Musick, J.A., Limpus, C.J. (1997): Habitat utilization and migration in juvenile sea turtles. In: Biology of Sea Turtles, p. 137-164. Lutz, P.L., Musick, J.A., Eds, CRC Press, Boca Raton.

Naro-Maciel, E., Formia, A. (2006): Sea turtle subpopulations and the IUCN Red List: a complemetary role for conservation genetics. Marine Turtle Newsletter 114: 68.

National Marine Fisheries Service, U.S., Service, F.a.W., SEMARNAT (2011): Bi-National Recovery Plan for the Kemp's Ridley sea turtle (Lepidochelys kempii) Silver Spring, Mariland, National Marine Fisheries Service.

Oliver, G., Pigno, A. (2005): First observation of a Kemp's ridley, Lepidochelys kempii (Garman, 1880), (Reptilia, Chelonii, Cheloniidae) on the French Mediterranean coasts. Bulletin de la Societe Herpetologique de France 116.

Owens, D.W., Ruiz, G.J. (1980): New methods of obtaining blood and cerebrospinal-fluid from marine turtles. Herpetologica 36: 17-20.

Pascual, X. (1985): Contribution of the study of marine turtles on Spanish coasts I. Distribution. Miscellania Zoologica (Barcelona) 9: 287-294.

Pasteur, G., Bons, J. (1960): Catalogue des reptiles actuels du Maroc. Travaux de l'Institute Scientifique Chérifien 21: 1-132. 
Pérea, C., Valdés, P., Pis-Millán, J.A. (2001): Tortugas marinas en la costa asturiana. In: XIV Reunión Bienal de la Sociedad Española de Historia Natural, p. 90. Murcia.

Piovano, S., Clusa, M., Carreras, C., Giacoma, C., Pascual, M., Cardona, L. (2011): Different growth rates between loggerhead sea turtles (Caretta caretta) of Mediterranean and Atlantic origin in the Mediterranean Sea. Mar. Biol. 158: 2577-2587.

Pritchard, P.C.H., Mortimer, J.A. (1999): Taxonomy, external morphology, and species identification. In: Research and Management Techniques for the Conservation of Sea Turtles, p. 21-38. Eckert, K.L., Bjorndal, A., AbreuGrobois, A., Donnelly, M., Eds, IUCN/SSC Marine Turtle Specialist Group Publication.

Proietti, M.C., Reisser, J.W., Kinas, P.G., Kerr, R., Monteiro, D.S., Marins, L.F., Secchi, E.R. (2012): Green turtle Chelonia mydas mixed stocks in the western South Atlantic, as revealed by mtDNA haplotypes and drifter trajectories. Mar. Ecol. Prog. Ser. 447: 195-209.

Putman, N.F., Shay, T.J., Lohmann, K.J. (2010): Is the geographic distribution of nesting in the Kemp's Ridley turtle shaped by the migratory needs of offspring? Integr. Comp. Biol. 50: 305-314.

Putman, N.F., Mansfield, K.L., He, R., Shaver, D.J., Verley, P. (2013): Predicting the distribution of oceanic-stage Kemp's ridley sea turtles. Biol. Lett. 9: 20130345.

Putman, N.F., Naro-Maciel, E. (2013): Finding the 'lost years' in green turtles: insights from ocean circulation models and genetic analysis. Proceedings Biological sciences/The Royal Society 280: 20131468.

Rees, A.F., Jony, M., Margaritoulis, D., Godley, B.J. (2008): Satellite tracking of a Green Turtle, Chelonia mydas, from Syria further highlights importance of North Africa for Mediterranean turtles. Zool. Middle East 45: 49-54.

Revelles, M., Carreras, C., Cardona, L., Marco, A., Bentivegna, F., Castillo, J.J., De Martino, G., Mons, J.L., Smith, M.B., Rico, C., Pascual, M., Aguilar, A. (2007): Evidence for an asymmetrical size exchange of loggerhead sea turtles between the Mediterranean and the Atlantic through the Straits of Gibraltar. J. Exp. Mar. Biol. Ecol. 349: 261-271.

Roberts, M.A., Schwartz, T.S., Karl, S.A. (2004): Global population genetic structure and male-mediated gene flow in the green sea turtle (Chelonia mydas): Analysis of microsatellite loci. Genetics 166: 1857-1870.

Roden, S.E., Morin, P.A., Frey, A., Balazs, G.H., Zarate, P., Cheng, I.J., Dutton, P.H. (2013): Green turtle population structure in the Pacific: new insights from single nucleotide polymorphisms and microsatellites. Endang. Species Res. 20: 227-234.

SEATURTLE.ORG Maptool (2002): http://www.seaturtle. org/maptool/. SEATURTLE.ORG, Inc.

Sella, I. (1982): Sea turtles in the eastern Mediterranean and northern Red Sea. In: Biology and Conservation of Sea Turtles, p. 417-423. Bjorndal, A., Ed., Smithsonian Institution Press, Washington DC.

Sheinin, A.P., Kerem, D., Macleod, C.D., Gazo, M., Chicote, C.A., Castellote, M. (2011): Gray whale (Eschrichtius robustus) in the Mediterranean Sea: anomalous event or early sign of climate-driven distribution change? Marine Biodiversity Records 4: 1-5.
Tomás, J., Fretey, J., Raga, A., Castroviejo, J. (2001): Tortues marines de la façade atlantique de l'Afrique. Genre Lepidochelys. 1. Quelques données concernant la présence de L. olivacea (Eschscholtz, 1829) dans l'îlle de Bioko (Guinée Équatoriale). Bulletin de la Societe Herpetologique de France 98: 31-42.

Tomás, J., Formia, A., Fernandez, M., Raga, J.A. (2003): Occurrence and genetic analysis of a Kemp's Ridley sea turtle (Lepidochelys kempii) in the Mediterranean Sea. Scientia Marina 67: 367-369.

Tomás, J., Gazo, M., Alvarez, C., Gozalbes, P., Perdiguero, D., Raga, J.A., Alegre, F. (2008): Is the Spanish coast within the regular nesting range of the Mediterranean loggerhead sea turtle (Caretta caretta)? Journal of the Marine Biological Association of the United Kingdom 88: $1509-1512$.

Tomás, J., Raga, J.A. (2008): Occurrence of Kemp's ridley sea turtle (Lepidochelys kempii) in the Mediterranean. Marine Biodiversity Records 5640: e58.

Vilaca, S.T., Vargas, S.M., Lara-Ruiz, P., Molfetti, E., Reis, E.C., Lobo-Hajdu, G., Soares, L.S., Santos, F.R. (2012): Nuclear markers reveal a complex introgression pattern among marine turtle species on the Brazilian coast. Mol. Ecol. 21: 4300-4312.

Wallace, B.P., DiMatteo, A.D., Hurley, B.J., Finkbeiner, E.M., Bolten, A.B., Chaloupka, M.Y., Hutchinson, B.J., Alberto Abreu-Grobois, F., Amorocho, D., Bjorndal, K.A., Bourjea, J., Bowen, B.W., Briseno Duenas, R., Casale, P., Choudhury, B.C., Costa, A., Dutton, P.H., Fallabrino, A., Girard, A., Girondot, M., Godfrey, M.H., Hamann, M., Lopez-Mendilaharsu, M., Marcovaldi, M.A., Mortimer, J.A., Musick, J.A., Nel, R., Pilcher, N.J., Seminoff, J.A., Troeng, S., Witherington, B., Mast, R.B. (2010): Regional management units for marine turtles: a novel framework for prioritizing conservation and research across multiple scales. Plos One 5.

Wallace, B.P., DiMatteo, A.D., Bolten, A.B., Chaloupka, M.Y., Hutchinson, B.J., Abreu-Grobois, F.A., Mortimer, J.A., Seminoff, J.A., Amorocho, D., Bjorndal, K.A., Bourjea, J., Bowen, B.W., Duenas, R.B., Casale, P., Choudhury, B.C., Costa, A., Dutton, P.H., Fallabrino, A., Finkbeiner, E.M., Girard, A., Girondot, M., Hamann, M., Hurley, B.J., Lopez-Mendilaharsu, M., Marcovaldi, M.A., Musick, J.A., Nel, R., Pilcher, N.J., Troeng, S., Witherington, B., Mast, R.B. (2011): Global conservation priorities for marine turtles. Plos One 6.

Witt, M.J., Penrose, R., Godley, B.J. (2007): Spatiotemporal patterns of juvenile marine turtle occurrence in waters of the European continental shelf. Mar. Biol. 151: $873-885$.

Zug, G.R., Kalb, H.J., Luzar, S.J. (1997): Age and growth in wild Kemp's ridley seaturtles Lepidochelys kempii from skeletochronological data. Biol. Conserv. 80: 261-268.

Submitted: June 29, 2013. Final revision received: October 23, 2013. Accepted: November 9, 2013.

Associated Editor: Sylvain Ursenbacher. 